\title{
Strategi Penanganan Krisis Kepariwisataan dalam Kebijakan Badan Nasional Penanggulangan Bencana (BNPB)
}

\author{
Nani Kurniasari \\ Kalbis Institute, Jl. Pulomas Selatan Kav. 22 Jakarta Timur 13210 \\ E-mail: nani.kurniasari@kalbis.ac.id
}

\begin{abstract}
Abstrak. Sebagai salah satu negara yang terletak di lempengan Indo-Australia dan Eurasia, Indonesia rawan terhadap berbagai jenis bencana alam seperti gunung meletus dan gempa bumi yang seringkali diikuti oleh tsunami. Bencana alam bisa terjadi kapan saja dan di mana saja, tidak terkecuali di wilayah-wilayah yang menjadi destinasi wisata. Ketika bencana alam melanda objek wisata Indonesia, saat itu pula organisasi kepariwisataan Indonesia mengalami krisis, di antaranya adalah objek wisata itu sendiri, hotel, restoran, dan semua organisasi terkait lainnya. Maka itu, diperlukan penanggulangan krisis yang tepat. Penelitian ini berusaha mengamati strategi penanganan krisis yang terjadi di sektor pariwisata Indonesia yang dilakukan oleh pemerintah, dalam hal ini adalah Badan Nasional Penanggulangan Bencana (BNPB). Menggunakan paradigma post-positivistik, penelitian ini di dekati secara kualitatif dengan strategi penelitian deskriptif melalui wawancara mendalam kepada informan terpilih, yaitu unsur pengarah BNPB Indonesia. Hasil penelitian ini menemukan bahwa Indonesia menangani krisis di sektor pariwisata dengan beberapa tahap seperti rehabilitasi, rekonstruksi, dan recovery (pemulihan) hingga build back better.
\end{abstract}

Kata kunci: bencana alam, kebijakan, krisis, pariwisata, strategi

\begin{abstract}
As one of the countries located on the Indo-Australian and Eurasian plates, Indonesia is vulnerable to various types of natural disasters such as erupting volcanoes and earthquakes that are often followed by tsunamis. Natural disasters can occur anytime and anywhere, not least in areas that become tourist destinations. When natural disasters struck the tourist attraction of Indonesia, at that time, Indonesian tourism organizations were experiencing crisis, such as tourist destination itself, hotel, restaurant, and all other related organizations. Therefore it is necessary to overcome the appropriate crisis. This research tries to observe crisis handling strategy that happened in the tourism sector by government, which is National Disaster Management Authority or Badan Nasional Penanggulangan Bencana (BNPB). Using postpositivism paradigm, this research approached qualitatively and was conducted with descriptive research strategy through in-depth interview of BNPB steering element representative. The study found that Indonesia handles the crisis in the tourism sector with rehabilitation, reconstruction, and recovery until build back better.
\end{abstract}

Keywords: natural disaster, policy, crisis, tourism, strategy 


\section{PENDAHULUAN}

Bencana alam yang kerap melanda destinasi wisata Indonesia adalah serangkaian peristiwa yang menciptakan tingginya tingkat ketidakpastian dan ancaman. Bencana terjadi ketika sumberdaya atau kapasitas yang tersedia sangat tidak memadai dalam mengatasi ancaman yang menyebabkan kerugian dan kehilangan nyawa, materi, dan lingkungan. Situasi ini adalah hasil dari kemerosotan di bidang ekologi, ekonomi, sosial, dan politik.

Pariwisata merupakan perjalanan dari satu tempat ke tempat lain, bersifat sementara, dilakukan perorangan maupun kelompok, sebagai usaha mencari keseimbangan atau keserasian dengan lingkungan hidup dalam dimensi sosial, budaya, alam, dan ilmu. Pariwisata yang berisiko ditandai dengan terjadinya bencana alam.

Kawasan Jawa Tengah dan DIY terkenal kaya dengan bangunan warisan budaya. Beberapa di antaranya telah diakui sebagai warisan budaya dunia, seperti Candi Borobudur, Candi Prambanan yang telah menjadi ikon pariwisata Indonesia. Candi Borobudur di Magelang tidak lepas dari hujan abu vulkanik letusan Gunung Merapi selama beberapa minggu. Abu Merapi paling banyak menyelimuti bagian timur, utara, dan selatan Candi Borobudur (Data BKPB). Berbagai bencana yang terjadi di Indonesia ternyata tidak menyebabkan pariwisata Indonesia menjadi terpuruk. Justru sektor pariwisata merupakan salah satu andalan Indonesia.

Secara akademis, penelitian ini diharapkan dapat menstimulasi penelitian-penelitian baru di ranah ilmu komunikasi yang secara teoretis dapat digunakan untuk memotivasi segala kegiatan komunikasi dan kebijakan publik yang digulirkan pemerintah. Secara praktis, penelitian ini diharapkan mampu memberikan identifikasi, representasi, analisis, visualisasi dari titik-titik terkait untuk penanggulangan pascakrisis bagi para stakeholder dan organisasi. Hasil penelitian dapat mendukung institusi atau lembaga pembuat kebijakan, khususnya dalam menyusun strategi kebijakan komunikasi krisis, dan secara umum dapat menjadi faktor penunjang yang strategis dalam menghasilkan kebijakan yang unggul bagi pemerintah.

Strategi adalah cara atau proses yang digunakan organisasi untuk mencapai misinya. Strategi komunikasi merupakan paduan dari perencanaan komunikasi dan manajemen komunikasi untuk mencapai suatu tujuan.

Kebijakan merupakan terjemahan dari kata 'policy' yang berasal dari bahasa Inggris, berarti sebagai sebuah rencana kegiatan atau pernyataan mengenai tujuan-tujuan, yang diajukan atau diadopsi oleh suatu pemerintahan, partai politik,

TABEL 1. Perkembangan Wisatawan Mancanegara 2008-2012

\begin{tabular}{|c|c|c|c|c|c|c|c|}
\hline \multirow[t]{2}{*}{ Tahun } & \multicolumn{2}{|c|}{ Wisatawan Mancanegara } & \multirow{2}{*}{$\begin{array}{c}\text { Rata-ra- } \\
\text { ta Lama } \\
\text { Tinggal } \\
\text { (hari) }\end{array}$} & \multicolumn{2}{|c|}{$\begin{array}{l}\text { Rata-rata Penge- } \\
\text { luaran Per Orang } \\
\text { (USD) }\end{array}$} & \multicolumn{2}{|c|}{ Penerimaan Devisa } \\
\hline & Jumlah & $\begin{array}{c}\text { Pertumbu- } \\
\text { han (\%) }\end{array}$ & & Per Hari & $\begin{array}{l}\text { Per Kun- } \\
\text { jungan }\end{array}$ & $\begin{array}{c}\text { Jumlah } \\
\text { (juta USD) }\end{array}$ & $\begin{array}{c}\text { Pertumbuhan } \\
(\%)\end{array}$ \\
\hline 2008 & $6,234,497$ & 13.24 & 8.58 & 137.38 & $1,178.54$ & $7,347.60$ & 37.44 \\
\hline 2009 & $6,323,730$ & 1.43 & 7.69 & 129.57 & 995.93 & $6,297.99$ & -14.29 \\
\hline 2010 & $7,002,944$ & 10.74 & 8,04 & 135.01 & $1,085.75$ & $7,603.45$ & 20.73 \\
\hline 2011 & $7,649,731$ & 9.24 & 7.84 & 142.69 & $1,118.26$ & $8,554.39$ & 12.51 \\
\hline 2012 & $8,044,462$ & 5.16 & 7.70 & 147.22 & $1,133.81$ & $9,120.85$ & 6.62 \\
\hline
\end{tabular}

Sumber: Pusdatin Kemenparekraf \& BPS 
dan lain-lain. Sebagai kebijakan publik, kebijakan komunikasi harus dirumuskan oleh lembaga pemerintah. Ini sesuai dengan pendapat James E. Anderson (dalam Islamy, 2002) yang mengatakan bahwa "public policies are those policies are developed by governmental bodies and officials."

Kebijakan komunikasi memiliki, paling tidak, lima kriteria, yaitu (1) memilikitujuantertentu,(2)berisitindakan pejabat pemerintah, (3) memperlihatkan apa yang akan dilakukan pemerintah, (4) bersifat positif atau negatif, dan (5) bersifat memaksa atau otoritatif. Rumusan kebijakan komunikasi hanya mungkin ideal bila pihak-pihak yang terlibat dalam pembuatan kebijakan komunikasi (communication policy network) berhasil mengidentifikasi kebutuhan masyarakat dan masalah komunikasi masyarakat yang harus direspons (Abrar, 2008).

Krisis adalah suatu peristiwa besar yang berpotensi negatif, dapat memengaruhi organisasi, perusahaan atau industri, publik, produk maupun jasa, bahkan nama baik. Krisis dapat menginterupsi bisnis yang sedang berjalan normal dan kadang-kadang dapat mengancam keberadaan organisasi.

Suatu perjalanan dianggap sebagai perjalanan wisata bila memenuhi tiga persyaratan yang diperlukan, yaitu: (1) harus bersifat sementara, (2) harus bersifat sukarela (voluntary) dalam arti tidak terjadi karena dipaksa, (3) tidak bekerja yang sifatnya menghasilkan upah ataupun bayaran (Kodhyat, 1983).

Menurut Smith (2002) faktor internal dalam suatu organisasi adalah (1) performance, meliputi kualitas barang dan jasa yang disediakan oleh organisasi, serta kelayakan dan ide pendukungnya, (2) ceruk, yaitu fungsi atau peran yang membuat organisasi berbeda dengan organisasi yang serupa, (3) struktur, berhubungan dengan alasan atau misi organisasi terkait situasi yang dihadapi organisasi, (4) rintangan internal, berupa hambatan yang dihadapi organisasi yang dapat membatasi efektivitas suatu program.

Masih menurut Smith (2002) faktor eksternal dalam suatu organisasi adalah (1) supporter, yaitu orang atau kelompok yang membantu organisasi untuk mencapai tujuan, (2) kompetitor, adalah orang atau organisasi yang memproduksi barang atau jasa yang sama dengan organisasi, (3) oposisi, adalah orang atau organisasi yang memusuhi organisasi, (4) rintangan eksternal, dapat berupa faktor sosial, ekonomi politik, yang dapat mengganggu kemampuan organisasi untuk mengatasi situasi.

\section{METODE}

Penelitian ini menggunakan paradigma post-positivistik. Dalam paradigma post-positivistik, meski penelitimengambil posisi objektif, mereka menyadari bahwa interaksi peneliti dan partisipan akan memengaruhi data (Poerwandari, 2011). Dalam penelitian ini, peneliti mengkaji strategi komunikasi sebagai hasil kebijakan dari pemerintah dan hal-hal terkait dalam pembentukan kebijakan tersebut.

Penelitian ini didekati secara kualitatif yang menghasilkan data deksriptif berupa kata-kata tertulis atau lisan dari orang-orang dan perilaku yang diamati. Strategi penelitian deskriptif digunakan untuk menggambarkan, mengemukakan, atau menguraikan berbagai data/teori yang telah ada (Mukhtar, 2007).

Data primer dalam penelitian ini dikumpulkan melalui wawancara mendalam dengan informan kunci dan narasumber yang memiliki kriteria bisa menjawab strategi kebijakan komunikasi krisis yang disertai pengamatan untuk menggali sebanyak mungkin informasi. Data utama juga didapat dari dokumen kebijakan komunikasi krisis Badan Nasional Penanggulangan Bencana (BNPB). Sementara, data sekunder diambil dengan cara studi dokumen, yakni mengumpulkan data pendukung 
seperti dokumentasi (foto), jurnal, tesis, disertasi, skripsi, buku, dan berbagai dokumen pendukung lainnya yang mengulas tentang industri pariwisata Indonesia, termasuk dari media massa yang memiliki kredibilitas tinggi.

Teknik analisis data dalam penelitian ini dilakukan dengan analisis kebijakan. Patton dan Savicky menjelaskan bahwa analisis kebijakan adalah tindakan yang diperlukan untuk dibuatnya sebuah kebijakan, baik kebijakan yang baru sama sekali, atau kebijakan yang dibuat sebagai konsekuensi dari kebijakan yang sudah ada. Peran analis kebijakan adalah memastikan bahwa kebijakan yang hendak diambil benar-benar dilandaskan atas manfaat optimal yang diterima oleh publik dan bukan asal menguntungkan pengambil kebijakan (Nugroho, 2012).

Penelitian kebijakan sedapat mungkin melihat berbagai aspek dari kebijakan agar dapat menghasilkan informasi yang lengkap. Informasi mengenai masalah-masalah yang dijawab oleh kebijakan serta masalah-masalah yang ditimbulkan dari penerapan kebijakan menjadi fokus dari analisis kebijakan.

Danim menyatakan bahwa proses penelitian kebijakan pada hakikatnya merupakan penelitian yang dimaksudkan guna melahirkan rekomendasi untuk pembuat kebijakan dalam rangka pemecahan masalah sosial. Kegiatan penelitian ini dilakukan untuk mendukung kebijakan (Danim, 2005).

Hasil yang ingin dicapai dari penelitian kebijakan adalah rekomendasi yang mungkin diperlukan pembuat kebijakan dalam rangka pemberian solusi terhadap masalah-masalah sosial. Rekomendasi yang dihasilkan dari proses penelitian kebijakan dapat berupa dukungan penuh terhadap kebijakan, kritik dan saran mengenai bagian mana dari kebijakan yang perlu diperbaiki, atau dapat juga berupa rekomendasi agar kebijakan tidak lagi diterapkan.

Karakteristik dari penelitian kebijakan secara terperinci dijelaskan oleh Allen D. Putt dan J. Fred Springer. Mereka menyatakan bahwa penelitian kebijakan dicirikan sebagai penelitian yang terfokus pada manusia, plural, multiperspektif, sistematis, berhubungan dengan keputusan, dan kreatif. Penelitian kebijakan tidak dapat dipisahkan dari konflik nilai dan kepentingan yang terdapat dari interaksi manusia.

Informasi yang diformulasikan dalam bentuk rekomendasi sebagai hasil yang ingin dicapai oleh penelitian kebijakan mengharuskan adanya pendekatan yang menyeluruh sehingga informasi yang dihasilkan juga dapat berupa rekomendasi yang sesuai dengan kondisi yang ada.

Analisis kebijakan menggabungkan lima prosedur umum yang lazim dipakai dalam pemecahan masalah manusia, yaitu definisi, prediksi, preskripsi, deskripsi dan evaluasi (Dunn, 2000). Menurut Dunn (2000) terdapat tiga bentuk analisis kebijakan, yaitu (1) analisis kebijakan prospektif, merupakan analisis kebijakan yang mengarahkan kajiannya pada konsekuensi-konsekuensi kebijakan sebelum suatu kebijakan diterapkan. Model ini dapat disebut sebagai model prediktif, (2) analisis kebijakan retrospektif, yaitu analisis kebijakan yang dilakukan terhadap akibat-akibat kebijakan setelah suatu kebijakan diimplementasikan. Model ini biasanya disebut sebagai model evaluatif, (3) analisis kebijakan integratif, merupakan bentuk perpaduan antara analisis kebijakan prospektif dan analisis kebijakan retrospektif.

\section{HASIL DAN PEMBAHASAN}

Peneliti mewawancarai Unsur Pengarah BNPB, yaitu dr. I Nyoman Kandun, M.Ph., ia bertugas merumuskan konsep kebijakan penanggulangan bencana nasional, memantau, dan menjalankan monitoring dan evaluasi (monev) sebagai masukan dalam menetapkan kebijakan-kebijakan yang 
akan dilakukan untuk penyelenggaraan penanggulangan bencana.

Informan pernah dikirim ke Manila untuk mengikuti pendidikan Master di bidang Epidemiologi dari University of the Phillipines System tahun 19781979. Mengikuti Field Epidemiology Training Program tahun 1982-1984 yang diselenggarakan oleh World Health Organization (WHO) dan CDC Atlanta, Epidemic Intelligence Service di CDC Atlanta, 1984.

Berbagai jabatan pernah dipegang di lingkungan Departemen Kesehatan yang berkaitan dengan penanganan bencana di bidang kesehatan sebagai koordinator penanganan bencana di bidang kesehatan. Beberapa kali menjadi Short Term Consultant (STC), Short Term Professional (STP), Temporary Adviser (TA) WHO. Tahun 2004 dikirim sebagai STP ke Maldives pascatsunami untuk menyelidiki wabah yang diduga disebabkan oleh West Nile Virus. Mendapat penghargaan dari UNICEF untuk Child Survival.

Sebagai salah satu unsur pengarah BNPB, informan dihadapkan pada tugas perumusan kebijakan hingga tahap evaluasi penanggulangan bencana. Terakhir, informan ditugaskan ke Bali untuk melatih kesiapsiagaan masyarakat dalam menghadapi bencana tsunami yang akan datang. Dalam hal ini, informan melatih para staf Hard Rock Hotel dalam rangka exercice tsunami. Dalam acara tersebut, para staf dilatih untuk melakukan penyelamatan diri ketika sirine tsunami dibunyikan, sehingga mereka cukup mempunyai waktu untuk meninggalkan lokasi rawan tsunami menuju tempat yang lebih aman. Dalam menjalankan tugas tersebut, pihak BNPB juga berkoordinasi dengan sektor pariwisata karena Bali merupakan daerah wisata. Berangkat dari tanggung jawab dan prestasinya tersebut, peneliti memilih informan sebagai salah satu informan dalam penelitian ini untuk menjawab pertanyaan mengenai strategi kebijakan dalam penanganan pascabencana dan alasan ditetapkannya kebijakan tersebut.

\section{Membuat Kebijakan}

Kebijakan

pemulihan

pascabencana di daerah pariwisata meliputi tahap rehabilitasi, rekonstruksi, dan recovery hingga build back better, yaitu ketika industri dapat berfungsi normal kembali, sehingga masyarakat bisa menjalankan fungsi-fungsi ekonominya, sebagaimana diungkapkan oleh informan pada 30 April 2014, pukul 16.30 WIB di Sekretariat Fetp Indonesia Ditjen PPPL Jakarta:

"recovery-nya ya kembalilah sebagai apa namanya build back better, semuanya kembali ke fungsi normal ya. Sekolah berfungsi kembali, ekonominya jalan. Jadi itu sifatnya koordinasi sektor-sektor."

Penyelenggaraan rehabilitasi di destinasi wisata yang terkena bencana alam merupakan tanggungjawab pemerintah pusat atau pemerintah daerah (pemda), dilaksanakan oleh satuan kerja (satker) pemda dan instansi terkait yang dikoordinasikan oleh Kepala Badan Penanggulangan Bencana Daerah (BPBD).

Dalam penentuan kebijakan rehabilitasi, prinsip dasar yang digunakan adalah menempatkan masyarakat tidak saja sebagai korban bencana, namun juga sebagai pelaku aktif dalam kegiatan rehabilitasi. Kegiatan rehabilitasi merupakan rangkaian kegiatan yang terintegrasi dengan kegiatan prabencana, tanggap darurat dan pemulihan dini (early recovery) serta kegiatan rekonstruksi.

Pemulihan dini adalah awal pemulihan pada fase darurat, dengan melengkapi/melanjutkan tindakan bantuan darurat, mendukung pemulihan spontan, dan meletakkan fondasi pemulihan jangka panjang. Pemulihan dini dilakukan oleh Rapid Assessment Team segera setelah terjadi bencana. 
Tahap selanjutnya adalah rehabilitasi, yaitu normalisasi fungsi, meliputi refungsionalisasi layanan dasar, mendampingi pemulihan spontan, menghidupkan kembali aktivitas ekonomi, menyediakan dukungan pemulihan kondisi psikologis dan sosial. Kemudian tahap rekonstruksi, yaitu restorasi komprehensif dan sepenuhnya dengan: (1) pembangunan kembali pelayanan, infrastruktur, penggantian bangunan rusak, (2) revitalisasi ekonomi, (3) pemulihan kehidupan sosial budaya, (4) pengurangan risiko bencana.

Program rehabilitasi dimulai segera setelah masa tanggap darurat dan diakhiri setelah tujuan utama rehabilitasi tercapai. Dalam pelaksanaan kegiatan rehabilitasi, pemerintah kabupaten/kota menggunakan dana penanggulangan bencana dari Anggaran Pendapatan Belanja Daerah (APBD) kabupaten/kota, jika tidak memadai, dapat meminta bantuan dana kepada pemerintah provinsi.

Tahap rehabilitasi meliputi perbaikan dan pemulihan semua aspek layanan publik sampai tingkat memadai. Sasaran utamanya adalah normalisasi atau berjalannya secara wajar berbagai aspek pemerintahan dan kehidupan masyarakat seperti pada kondisi sebelum terjadinya bencana.

Tahap rekonstruksi mencakup pembangunan kembali semua prasarana dan sarana serta kelembagaan pada wilayah pascabencana. Build back better dengan pengurangan risiko bencana. Sasaran utamanya adalah tumbuh kembangnya kegiatan ekonomi, sosial dan budaya, tegaknya hukum dan ketertiban, serta bangkitnya peran masyarakat dalam segala aspek kehidupan.

Strategi penyelenggaraan kegiatan rehabilitasi adalah melibatkan dan memberdayakan masyarakat dalam tahapan pelaksanaan rehabilitasi. Memerhatikan karakter bencana, daerah dan budaya masyarakat setempat. Mendasarkan pada kondisi aktual di lapangan (tingkat kerugian/kerusakan serta kendala medan). Menjadikan kegiatan rehabilitasi sebagai gerakan dalam masyarakat dengan menghimpun masyarakat sebagai korban maupun pelaku aktif kegiatan rehabilitasi dalam kelompok swadaya. Menyalurkan bantuan pada saat, bentuk, dan besaran yang tepat sehingga dapat membangkitkan gerakan rehabilitasi dan penanganan bencana yang menyeluruh.

Sasaran kegiatan rehabilitasi adalah kelompok manusia dan segenap kehidupan dan penghidupan yang terganggu oleh bencana, sumberdaya buatan yang mengalami kerusakan akibat bencana sehingga berkurang nilai gunanya, serta ekosistem atau lingkungan alam untuk mengembalikan fungsi ekologisnya.

Dalam hal pemerintah daerah memerlukan dukungan kapasitas bagi pelaksanaan rehabilitasi dan rekonstruksi, maka dapat dibentuk tim teknis di tingkat pusat yang dikoordinasikan BNPB dan bertugas memberikan bantuan teknis bagi pelaksanaan rehabilitasi dan rekonstruksi oleh pemerintah daerah, yang selanjutnya ditetapkan struktur kelembagaan dan tanggung jawabnya oleh Pemerintah.

"Sebetulnya kan bencana itu kan rumusnya $\mathrm{D}=\mathrm{H} \times \mathrm{V}$ : $\mathrm{C}$ kan. D-nya disaster, H-nya adalah hazard, V-nya adalah vulnerability, masyarakatnya vulner atau tidak. C-nya capacity, dengan capacity kan. Jadi itu ukuran D-nya itu bisa capacity-nya diperbesar atau V-nya, di main-maininnya di situ. Nah dalam ada masing-masing bisa diterjemahkan kenapa. Nah masyarakat yang di departemen juga bisa berperan di masing-masing variabel itu, apakah hazard-nya, pengurangan vulnerability-nya gitu ya. Jadi bisa dinumerator kapasitasnya apa. Capacity to detect, capacity to report, capacity to respons ya." (Informan, 30 April 2014, pukul 16.30 WIB, Sekretariat Fetp Indonesia Ditjen PPPL, Jakarta). 
Sebagaimana disampaikan informan bahwa rumus yang digunakan untuk menangani bencana adalah $\mathrm{D}=\mathrm{H}$ x V : C. D (disaster), H (hazard), yaitu karakteristik bahaya atau ancaman. V (vulnerability), yaitu sikap atau perilaku yang mengakibatkan penurunan kualitas sumberdaya alam atau kerentanan, C (capacity), yaitu kapasitas.

Kebutuhan rehabilitasi dan rekonstruksi diperkirakan berdasarkan penilaian kerusakan dan kerugian Damages and Losses Assessment (DaLA) yang dilaksanakan oleh BNPB, Bappenas dan Bank Dunia, serta dilengkapi dengan penelitian kebutuhan masyarakat korban bencana/Human Recovery Needs Assessment (HRNA) yang dilaksanakan oleh Inter Agency Steering Committee yang dikoordinasikan oleh UNDP untuk memperoleh gambaran kebutuhan pemulihan pasca bencana atau Post Disaster Needs Assessment.

Penilaian dilakukan untuk melihat sampai sejauh mana kerusakan yang terjadi akibat bencana alam di kawasan wisata. Aspek apa saja yang terkena. Penilaian tersebut mencakup semua aspek layanan masyarakat, termasuk aktivitas bisnis masyarakat. Keterkaitan antara DaLA dengan HRNA memberikan umpan balik bagi kebutuhan pemulihan dengan menempatkan masyarakat korban bencana dan lingkungan budidaya dan non-budidaya sebagai sasaran pemulihan pascabencana.

\section{Menggalang Kerjasama dengan Sektor Terkait}

Koordinasi juga dilakukan
dengan

dan Ekonomi Kreatif Republik Indonesia (Kemenparekraf RI). Seperti penyelenggaraan pelatihan mengantisipasi tsunami yang akan datang. Acara ini digelar pertama kali di Hard Rock Hotel Bali. BNPB berperan sebagai pihak yang melatih kesiapsiagaan dalam menyikapi sirine tsunami.
"Tergantung daerah itu ada pariwisatanya atau tidak. Seperti di Bali ya koordinasi dengan pariwisata. Seperti kemarin saya baru dari Bali. Ya saya kan baru dari sana. Dari Bali itu, di situ kan ada exercise tsunami ya. Yang exercice Hard Rock Hotel, bagaimana kesiapsiagaan mereka. Nah kemudian nanti hotel-hotel lain juga akan. Nah itu dilatih dia, untuk melakukan ke mana itu, apa namanya, terhadap sirine tsunami yang akan datang, dia cukup waktu untuk pergi ke mana." (Informan, 30 April 2014, pukul 16.30 WIB, Sekretariat Fetp Indonesia Ditjen PPPL, Jakarta).

Tahap pemulihan meliputi tahap rehabilitasi dan rekonstruksi. Upaya yang dilakukan pada tahap rehabilitasi adalah perbaikan untuk mengembalikan fungsi sarana dan prasarana yang terkena bencana ke kondisi normal yang lebih baik agar kehidupan dan penghidupan masyarakat dapat berjalan kembali khususnya kegiatan sektor ekonomi.

Kegiatan yang dilakukan meliputi perbaikan sarana dan prasarana sosial dan ekonomi. Pemulihan kejiwaan pascabencana (post traumatic stress) melalui konseling, penyuluhan, terapi kelompok (di sekolah, kelompok pengungsi) dan perawatan. Pemulihan kesehatan termasuk gizi. Pemulihan sosial ekonomi sebagai upaya peningkatan ketahanan pangan. Program yang dapat dilakukan antara lain penciptaan lapangan kerja, pemberian modal usaha, perbaikan sumber-sumber bahan pangan, dan lainnya.

"BNPB menangani rehabilitasi, rekonstruksi, dan recovery. Ada divisi 1, divisi 2, divisi 3, dan divisi 4. Divisi 1 adalah Pengurangan Risiko Bencana (PRB), divisi 2 adalah tanggap darurat, kemudian ada divisi yang mengurus rehabilitasi, rekonstruksi, sampai recovery. Kerja sektor-sektor BNPB itu bersifat koordinasi sesuai dengan 
UU 24 2007. Kemudian Peraturan Pemerintah yang dipakai adalah PP 20, 21, 22. Recovery adalah kembali sebagai build back better, semua kembali ke fungsi normal." (Informan, 30 April 2014, pukul 16.30 WIB, Sekretariat Fetp Indonesia Ditjen PPPL, Jakarta).

Tahap rekonstruksi merupakan tahap untuk membangun kembali sarana dan prasarana yang rusak akibat bencana secara lebih baik dan sempurna, sehingga pembangunannya harus dilakukan dengan perencanaan yang baik melalui kajian dari berbagai ahli dan sektor terkait. Kegiatan dalam tahap rekonstruksi dapat berupa melakukan kajian dan inventarisasi berbagai kerusakan, menyusun rencana pembangunan kembali secara konseptual, terintegrasi, dan berkesinambungan agar hasilnya lebih baik dari keadaan semula. Melakukan penelitian sebabsebab kerusakan. Menentukan prioritas pelaksanaan pembangunan. Melakukan monitoring dan evaluasi. Hal ini diperkuat dengan pernyataan informan pada 30 April 2014, pukul 16.30 WIB di Sekretariat Fetp Indonesia Ditjen PPPL Jakarta, bahwa:

\footnotetext{
"Sebagai contoh, kecamatan A atau kabupaten A terkena bencana, seluruh siklus bencana ditangani, dilakukan rehabilitasi, rekonstruksi, sampai recovery".
}

Pelaksanaan rehabilitasi dan rekonstruksi dimulai setelah masa tanggap darurat diumumkan oleh Pemerintah. Pemerintah melalui BNPB bertugas memberikanarahan kebijakan, pemerintah provinsi bertugas memberikan arahan teknis berupa pedoman operasional, sedangkan pemerintah kabupaten/kota bertugas melaksanakan rehabilitasi dan rekonstruksi sesuai pedoman operasional yang disusun oleh pemerintah provinsi.

Di tingkat kabupaten/kota dibentuk klinik rehabilitasi dan rekonstruksi sebagai forum koordinasi di antara Satuan Kerja Perangkat Daerah (SKPD) dan pelayanan bagi masyarakat, sedangkan di tingkat kecamatan dibentuk unit pemantauan untuk memastikan kegiatan pemulihan dan penyaluran dana yang dilaksanakan tepat sasaran dan akuntabel.

Penanggulangan bencana pada tahap rehabilitasi dan rekonstruksi mengalami beberapa kendala. Selama beberapa dekade, upaya penanggulangan bencana berjalan melalui mekanisme yang sepenuhnya dikendalikan pemerintah terutama pemerintah pusat. Dominasi pemerintah pusat berdampak pada tingkat ketergantungan daerah terhadap pemerintah pusat yang sangat tinggi, sehingga setiap terjadi bencana betapapun kecilnya, daerah selalu meminta bantuan kepada pusat, sehingga kemampuan daerah dalam menanggulangi bencana kurang meningkat.

Selain itu, keterlambatan dalam penanggulangan bencana akibat luasnya wilayah negara Indonesia dan sarana transportasi yang terbatas untuk menjangkau daerah sulit mengakibatkan terlambatnya bantuan logistik kepada korban bencana. Untuk itu sangat diperlukan penguatan kemampuan kelembagaan Badan Penaggulangan Bencana Daerah (BPBD), pemerintah provinsi, dan pemerintah kabupaten/kota.

\section{Penerapan Strategi Penanganan Krisis Kepariwisataan dalam Kebijakan BNPB}

\section{Gempa Bumi Sumatera Barat}

Gempa bumi tektonik yang cukup besar di Sumatera Barat terjadi pada hari Rabu (30/09) pukul 17:16:09 WIB dengan kekuatan 7,6 Skala Richter (SR) di sekitar $57 \mathrm{~km}$ arah Barat Daya Pariaman Sumatera Barat dengan lokasi 0,84 LS dan 99,65 BT pada kedalaman 71 $\mathrm{km}$.

Selama tanggap darurat, BNPB pada dasarnya sudah berusaha untuk bekerja maksimal. Posko yang dibangun BNPB dapat mendukung kinerja Satkorlak 
Provinsi Sumatera Barat maupun Satlak Kabupaten/Kota. BNPB juga dengan cepat mengirimkan bantuan dalam bentuk dana operasional, tenda, maupun bantuan logistik yang dibutuhkan. BNPB juga sudah mencoba bekerja keras melakukan pendataan kerusakan didukung oleh Satlak Kabupaten/Kota, dan Satkorlak Sumatera Barat.

$\begin{array}{cc}\text { Peran } & \text { BNPB semakin dirasakan } \\ \text { dengan } & \text { upayanya melakukan }\end{array}$
pendampingan kepada pemerintah daerah provinsi Sumatera Barat dan memperkuat koordinasi di antara kementerian lembaga pemerintah yang terkait, termasuk dengan organisasi nonpemerintah, dunia usaha dan industri.

Pada tahap tanggap darurat, pemerintah masih dianggap terlambat dalam evakuasi dan pemberian bantuan. Konsentrasi kegiatan pada awalnya di Kota Padang, sementara Kabupaten Padang Pariaman dan Kota Pariaman kurang mendapat prioritas. Sementara itu, pada saat tanggap darurat, birokrasi masih dinilai menghambat distribusi bantuan. Dalam hal ini bantuan yang diharapkan masyarakat saat itu justru banyak menumpuk di Bandara Minangkabau, Pelabuhan Telukbanyur, Satkorlak di pendopo Gubernur, Satlak PB di Kota/Kabupaten. Lebih dari itu, di bandara Halim Perdana Kusuma juga masih menumpuk bantuan yang harus segera dikirim ke Sumatera Barat.

Koordinasi penanganan bencana telah dicoba dilakukan, namun belum maksimal. Misalnya Cluster Meeting antara instansi terkait, NGO internasional, juga tim rescue asing kurang efektif sehingga fungsi komando tidak bisa berjalan secara maksimal. Karakteristik perilaku korban bencana gempa bumi di Sumatera Barat menggambarkan kecenderungan bertindak sendiri-sendiri dan tak terkoordinasi, sehingga tidak mudah mengarahkan mereka untuk dikonsentrasikan pada suatu lokasi/ barak pengungsian. Pengungsi menyebar dengan menumpang ke sanak saudara, tetangga atau di dekat rumah tinggalnya yang rusak atau ambruk. Sehingga setiap ditanya media massa selalu akan menjawab belum mendapatkan bantuan.

Sumber data jumlah korban yang meninggal, luka berat, luka ringan sempat mengalami kesimpangsiuran. Data yang muncul ke ruang publik berbeda antara yang dikeluarkan BNPB, Satkorlak, Crisis Center Departemen Sosial, Pusat Penanggulangan Krisis, Departemen Kesehatan dan Satlak Kabupaten/Kota.

Pemerintah masih dinilai mengalami keterlambatan dalam melakukan pemetaan lokasi korban. Pemetaan di masing-masing desa dan logistik yang sudah diberikan tidak bisa dijadikan pedoman untuk mengatur distribusi bantuan dengan cepat dan tepat. Terkait dengan ketidakjelasan distribusi bantuan, sempat memunculkan isu etnis karena korban gempa di Malalak yang mayoritas keturunan Tionghoa merasa belum mendapatkan bantuan yang proporsional.

Komunikasi dengan media masih dinilai kurang berjalan efektif menyebabkan banyak media yang langsung mencari berita ke lapangan yang kadang tidak terverifikasi dengan baik, sementara itu banyak media massa yang tidak menjalankan etika jurnalisme dalam pewartaan berita bencana secara benar.

Pada saat tanggap darurat yang sangat diharapkan adalah terjalinnya koordinasi yang lebih efektif. Dalam situasi seperti ini yang diperlukan adalah penyelenggaraan Cluster Meeting secara berkala. Dari kegiatan ini dapat dikoordinasikan berbagai masalah dari berbagai sektor pelaku tanggap darurat baik SKPD Kabupaten/Kota, Provinsi dan Instansi Pusat/Departemen serta NGO lokal, nasional, internasional, dan organisasi PBB atau internasional. Dalam forum ini dapat dilakukan monitoring rincian perkembangan kegiatan sekaligus pemecahan masalah dan jalan keluar. Dalam kondisi seperti ini penunjukkan 
Liason Officer yang kuat/kompeten di bawah koordinasi BNPB menjadi sangat dibutuhkan untuk menjembatani kerjasama di antara lembaga terkait.

Dalam rangka mempermudah dan menghindari isu diskriminasi distribusi bantuan logistik, sebenarnya dapat dihindari jika dilakukan pemetaan (mapping) sasaran/korban bencana. Dari pemetaan yang tepat akan dapat dimonitor dan dievaluasi proses distribusi. Pemanfaatan sumber daya yang ada, yaitu LSM/relawan nasional/ internasional, masyarakat, serta aparat desa sangat membantu proses distribusi tersebut, terutama terkait dengan distribusi kebutuhan dasar seperti air bersih, makanan, dan tempat berteduh.

Menghadapi korban bencana seperti yang terjadi di Sumatera Barat ini diperlukan klinik kesehatan mobile terpadu dalam jumlah yang memadai. Frekuensi mobilitas kesehatan mobile ini diatur agar dapat menjangkau semua korban gempa (sasaran). Aktivitas ini dilakukan secara berkala hingga fungsi Puskesmas dapat berjalan normal kembali. Aktivitas mobile kesehatan ini sangat efektif untuk mencegah dan menekan penyebaran penyakit menular pascagempa.

Image building penanganan kebencanaan yang telah dan tengah berjalan harus tetap mendapat perhatian, karena dalam tahap tanggap darurat ini layak dibangun pemahaman bahwa BNPB bukan representasi dari apa yang disebut inertia bureaucracy-birokrasi yang bebal dan lamban, melainkan sebuah institusi yang telah berusaha mengambil peran sebagai komando, mengkoordinasi semua stakeholder baik dari dalam dan luar negeri sesuai perencanaan yang dibuat dengan patokan-patokan UU dan peraturan yang berlaku. Dalam konteks ini memperkuat fungsi Humas di BNPB maupun di BPBD Provinsi dan BPBD Kabupaten/Kota adalah sebuah keniscayaan, untuk menyampaikan informasi secara berkala sehingga publik melalui media massa maupun langsung bisa mendapatkan informasi yang dibutuhkan sekaligus untuk menghindari kesimpangsiuran berita burung yang tak bertanggung jawab.

\section{Letusan Gunung Merapi}

Pemulihan awal (early recovery) 4 bulan, dimulai dari bulan JanuariApril 2011. Early recovery muncul dilatarbelakangi dengan kenyataan bagitu banyak persoalan pemenuhan kebutuhan dasar warga penyintas (survivor) belum dapat terpenuhi, padahal masa tanggap darurat sudah berakhir dan memasuki tahap rehabilitasi dan rekonstruksi.

Dasar perencanaan Rencana Aksi Rehabilitasi dan Rekonstruksi (Renaksi RR) bencana primer erupsi Merapi menggunakan data kerusakan dan kerugian sampai 31 Desember 2010. Belajar dari penyusunan renaksi RR bencana primer yang kurang terkoordinasi di antara KL, maka dalam penyusunan renaksi bencana sekunder lahar dingin direkomendasikan sebagai berikut:

(1) Diharapkan BNPB lebih bisa mengkordinasikan semua pemikiran dan masukan dari semua KL sejak perencanaan, implementasi, dan evaluasi.

(2) Oleh karena penanggung jawab penyusunan renaksi harus ditetapkan berdasarkan tingkat bencana (Perka BNPB 17/2010) maka dengan demikian harus segera ada penetapan tingkat bencana sekunder lahar dingin agar bisa ditetapkan penanggung jawab penyusun renaksi. Keterlambatan penetapan level bencana akan memengaruhi kesiapan dan kecepatan melakukan RR.

(3) Dari segi konten renaksi seharusnya tidak hanya berkaitan dengan DaLA, tetapi juga harus dimasukkan Human Resources Need Assessment (HRNA).

Kecepatan perubahan situasi bencana di lapangan tidak bisa diikuti 
oleh langkah percepatan penetapan kebijakan, program, dan perencanaan anggaran. Masyarakat yang tinggal di KRB III tersebut hendak ditetapkan sebagai kawasan dilarang untuk hunian. Dalam kaitan ini direkomendasikan sebagai berikut:

(1) Perlu segera dilakukan penetapan zonasi yang bisa dijadikan pedoman dan kepastian warga menentukan kehidupannya ke depan.

(2) Perlu ada pendekatan sosiologis yang tepat untuk memberi pengertian kepada masyarakat yang terkena zona larangan hunian (KRB III) agar bersedia mematuhi ketentuan tidak menghuni zona larangan tersebut.

\section{Banjir Bandang Wasior, Papua Barat}

Kegiatan rehabilitasi adalah tanggung jawab Pemerintah dan/atau Pemerintah Daerah yang terkena bencana. Sebagai wujud dari rasa tanggung jawab itu, masing-masing satuan kerja pemerintah daerah dan instansi/lembaga terkait yang dikoordinasikan oleh kepala BPBD telah melakukan banyak hal dengan semangat build back better. Namun karena berbagai keterbatasan yang dihadapi, sampai dengan 20 Juni 2011 penanganan pascabencana di Wasior yang terjadi pada tanggal 4 Oktober 2010 belum memasuki tahap rehabilitasi dan rekonstruksi. Selama kurang lebih 8 bulan terakhir, semangat build back better tersebut baru memasuki pemulihan awal (early recovery).

Dalam penentuan kebijakan pemulihan awal pemerintah setempat telah berupaya menerapkan acuan yang ada, dalam hal ini menempatkan masyarakat tidak saja sebagai korban bencana, namun juga sebagai pelaku aktif dalam kegiatan pemulihan. Demikian juga kegiatan pemulihan awal tersebut dilaksanakan dalam sebuah rangkaian kegiatan yang terkait dan terintegrasi sejak tanggap darurat dan pemulihan dini serta kegiatan rekonstruksi.
Pelaksanaan pemulihan awal pemerintah kabupaten Telok Wondama telah berupaya melibatkan dan memberdayakan masyarakat. Dalam penanganan awal, pemerintah setempat jugatelahmemerhatikankarakter bencana, daerah, dan budaya masyarakat setempat. Di samping dalam kegiatan pemulihan awal ini telah berupaya menempatkan masyarakat tidak hanya sebagai korban namun sekaligus sebagai pelaku aktif dalam kelompok swadaya yang bergerak bersama melakukan pemulihan.

\section{Strategi Kebijakan Komunikasi Krisis Responsif}

Strategi kebijakan komunikasi dalam krisis kepariwisataan meliputi perencanaan dan manajemen komunikasi yang terbentuk dari prinsip-prinsip dan norma-norma yang sudah ada untuk mengatasi peristiwa besar berpotensi negatif yang terjadi di sektor pariwisata. Krisis yang menimpa sektor pariwisata Indonesia direspons dengan berbagai cara mulai dari rehabilitasi, rekonstruksi, hingga pemulihan. Semua tahapan dalam merespons krisis yang terjadi membentuk reputasi pariwisata Indonesia di mata dunia.

Terkait dengan penelitian mengenai krisis situasional di sektor pariwisata juga perlu adanya respons yang cepat untuk menjelaskan, baik kepada korban maupun kepada publik secara umum mengenai apa yang terjadi pada sektor pariwisata tersebut dan tahap penanggulangan apa saja yang sudah dilakukan. Hal ini adalah prioritas pertama untuk menggaransi keamanan dan kebertahanan ketika menghadapi situasi krisis.

Proses strategi kebijakan komunikasi krisis di sektor pariwisata Indonesia bersifat responsif. Hal ini ditandai dengan proses yang dilalui dalam merespons adalah rehabilitasi, rekonstruksi, dan recovery. Semua tahapan proses ini dilakukan untuk merespons krisis yang terjadi secara tiba-tiba. Kemudian, perlakuan dalam 
menangani pascakrisis juga berbeda antara satu daerah wisata yang terdampak krisis dengan kawasan wisata lainnya yang mengalami krisis serupa. Dengan kata lain, penanganan yang dilakukan bersifat insidental dan responsif.

Strategi kebijakan komunikasi krisis di sektor pariwisata Indonesia disebut responsif karena informan dalam penelitian ini menjelaskan bahwa krisis yang terjadi ditangani dengan melakukan inovasi berdasarkan penanganan krisis yang pernah terjadi di masa lalu. Data memperlihatkan bahwa setiap terjadi krisis, penanganan selalu bersifat merespons krisis yang ada dengan melakukan hal-hal yang sudah menjadi tanggung jawab lembaga.

\section{Faktor Pembentuk Strategi Kebijakan Komunikasi Krisis di Sektor Pariwisata Indonesia}

Faktor internal yang membentuk strategi kebijakan komunikasi krisis di sektor pariwisata Indonesia adalah (1) potensi kawasan objek wisata, hal ini bisa dilakukan dengan upaya penemuan destinasibaru,(2)sumberdayamanusia,(3) pengelolaan kawasan wisata, (4) regulasi, pembuatan kebijakan yang berpihak pada peningkatan kualitas kepariwisataan sangat diperlukan termasuk kebijakan mengenai pengembangan sumberdaya manusia di bidang kepariwisataan untuk mempercepat pertumbuhan sektor pariwisata Indonesia, (5) promosi, strategi komunikasi pemasaran merupakan salah satu faktor yang dapat meningkatkan minat wisatawan untuk berkunjung ke salah satu destinasi wisata, pemasaran destinasi pariwisata berorientasi pada permintaan, kepuasan, dan nilai-nilai wisatawan di dalam dan di luar negeri berdasarkan segmentasi dan target pasar tertentu, pemilihan media promosi yang tidak tepat dapat menimbulkan banyak hambatan dalam strategi berkomunikasi untuk mencapai tujuan, pemasaran destinasi pariwisata salah satunya dapat dilakukan melalui kegiatan pengembangan promosi dan komunikasi yang terdiri dari kegiatan kehumasan, publikasi, penjualan secara personal, dan promosi penjualan (pemasaran langsung, pameran, forum bisnis, sponsor, periklanan serta pemasaran elektronik).

Strategi kebijakan komunikasi krisis di sektor pariwisata Indonesia juga dibentuk oleh beberapa faktor eksternal, di antaranya adalah (1) adanya kesamaan visi dan misi di antara para stakeholder, (2) antusiasme para pelaku usaha, (3) pilihan wisatawan, (4) kesadaran wisatawan terhadap objek wisata, (5) persaingan di antara destinasi wisata.

\section{SIMPULAN}

\section{Implementasi Strategi Kebijakan Komunikasi Krisis di Sektor Pariwisata Indonesia}

Kebijakan komunikasi

krisis di sektor pariwisata Indonesia diimplementasikan dengan beberapa langkah strategis, yaitu, rehabilitasi, rekonstruksi, dan recovery. Langkah pertama adalah rehabilitasi. Upaya yang dilakukan pada tahap rehabilitasi adalah perbaikan untuk mengembalikan fungsi sarana dan prasarana yang terkena bencana ke kondisi normal yang lebih baik agar kehidupan dan penghidupan masyarakat dapat berjalan kembali khususnya kegiatan sektor ekonomi.

Kegiatan yang dilakukan dalam tahap rehabilitasi meliputi: (1) perbaikan sarana dan prasarana sosial dan ekonomi; (2) pemulihan kejiwaan pascabencana/ post traumatic stress melalui konseling, penyuluhan, terapi kelompok di sekolah, kelompok pengungsi, dan lain-lain; dan (3) pemulihan kesehatan termasuk gizi, (4) pemulihan sosial ekonomi sebagai upaya peningkatan ketahanan masyarakat.

Langkah kedua yaitu rekonstruksi. Tahap rekonstruksi merupakan tahap untuk mebangun kembali sarana dan prasarana yang rusak akibat bencana secara labih baik dan sempurna. Sehingga pembangunannya harus dilakukan dengan perencanaan yang baik melalui kajian 
dari berbagai ahli dan sektor terkait.

Kegiatan dalam tahap rekonstruksi dapat berupa: (1) melakukan kajian dan inventarisasi berbagai kerusakan; (2) menyusun rencana pembangunan kembali secara konseptual, terintegrasi, dan berkesinambungan agar hasilnya lebih baik dari keadaan semula; (3) melakukan penelitian sebab-sebab kerusakan; (4) menentukan prioritas pelaksanaan pembangunan; dan (5) melakukan monitoring dan evaluasi.

Krisis yang menimpa sektor pariwisata Indonesia tidak terbatas pada bencana alam, namun juga bisa berupa krisis yang disebabkan oleh gejolak politik, pencemaran nama baik, kecelakaan pesawat, dan lain-lain yang berakibat pada buruknya citra suatu negara atau suatu organisasi. Oleh karena itu diperlukan juga penelitian untuk mengembalikan reputasi suatu wilayah atau sebuah organisasi setelah krisis-krisis tersebut sudah selesai diatasi. Penelitian ini hanya terbatas pada penanganan pascabencana alam yang terjadi di sektor pariwisata Indonesia.

\section{DAFTAR PUSTAKA}

Abrar, A. N. (2008). Kebijakan Komunikasi: Konsep, Hakekat dan Praktek. Yogyakarta: Gava Media.

Danim, S. (2005). Pengantar Studi Penelitian Kebijakan. Jakarta: PT. Bumi Aksara.
Dunn, W. N. (2000). Pengantar Analisis Kebijakan Publik. Yogyakarta: Gajah Mada University Press.

Islamy, M. I. (2002). Prinsip-Prinsip Perumusan Kebijaksanaan Negara. Jakarta: Bumi Aksara.

Kandun, I. N. (2014). Wawancara personal, dilakukan satu kali di Sekretariat Fetp Indonesia, Ditjen PPPL. J1. Percetakan Negara No. 2910560.

Mukhtar. (2007). Bimbingan Skripsi, Tesis dan Artikel Ilmiah: Panduan Berbasis Penelitian Kualitatif Lapangan dan Perpustakaan. Jakarta: Gaung Persada Press.

Nugroho, R. D. (2012). Public Policy. Edisi keempat revisi. Jakarta: Elex Media Komputindo.

Poerwandari, E. K. (2011). Pendekatan Kualitatif. Edisi ketiga. Depok: lembaga Pengembangan Sarana Pengukuran dan Pendidikan Psikologi (LPSP3) Universitas Indonesia. Putt, Allen D. dan J. Fred Springer. (1989). Policy Research; Concepts, Methods, and Application. New Jersey: Prentice Hall.

Pusat Data dan Informasi Kementerian Pariwisata dan Ekonomi Kreatif dan Badan Pusat Statistik (Pusdatin Kemenparekraf \& BPS) Perkembangan Wisatawan Mancanegara 2008-2012.

Smith, R. D. (2002). Strategic Planning for Public Relation. Mahwah, NJ: Lawrence Erlbaum Assosiates. 